\title{
IAMJ
}

INTERNATIONAL

AYURVEDIC

MEDICAL JOURNAL

Review Article

ISSN: 2320-5091

Impact Factor: 6.719

\section{AYURVEDA SAMHITHA BASED LITERATURE REVIEW ON JWARA AND RELEVANCE OF JWARA CENTERED APPROACH IN MANAGEMENT OF COVID-19}

\author{
Visakh V', Soumya Saraswathi $M^{2}$ \\ ${ }^{1}$ PG Scholar, Dept. of Ayurveda Samhita and Siddhanta, Alvas Ayurveda MedicalCollege, Moodbidri, Karnataka, \\ India \\ ${ }^{2}$ Professor, Dept. of Ayurveda Samhita and Siddhanta, Alvas Ayurveda MedicalCollege, Moodbidri, Karnataka, \\ India
}

Corresponding Author: visakh.freekick@gmail.com

https://doi.org/10.46607/iamj3709102021

(Published Online: October 2021)

Open Access

(C) International Ayurvedic Medical Journal, India 2021

Article Received: 30/09//2021 - Peer Reviewed: 07/10/2021 - Accepted for Publication: 08/10/2021

\section{Check for updates}

\begin{abstract}
Pyrexia (fever) is one of the prevalent symptoms in COVID-19. Many studies show that more than half of infected patients are suffering from fever. In Ayurveda Jwara (fever) is considered a major disease that needed to be carefully evaluated and managed. Thus, an Ayurveda Samhithas based literature review on Jwara can shape a better understanding and management approach for Jwara. A retrospective literature review with Jwara based on Samhithas can enhance the approach and treatment strategies, which can repurpose with any emerging diseases. A Jwara chikitsa approach towards COVID-19 may provide better understanding and outcomes in the current disease management strategies.
\end{abstract}

Keywords: Jwara, COVID-19, Jwara Chikitsa.

\section{INTRODUCTION}

Jwara (Fever) has utmost importance in Ayurveda Samhithas as it is dealt with as the primary disease to be discussed in chapters of Chikitsa sthanas among the Brihathrayees. The Jwara is considered the emperor for all other diseases. As per the mythological explanation Jwara is supposed to be originated from the ultimate Anger of Shiva ${ }^{1}$. The increased body tempera- 
ture and its manifestation are proposed to be descended from the Anger of Shiva. Apart from the mythological origin, there is an extensive and depth analysis on Jwara based on its Nidana (cause), Samprapthi (etiopathogenesis) Rupa (manifestation) Chikitsa (treatment) is there in the Samhitas. Jwara is also considered to be the process by which a living organism disintegrated and eventually die $^{2}$. Manifestation and understanding of Jwara thus arise as a universal phenomenon that is related to all living organisms rather than just a disease affecting humans. Ayurveda considers Jwara (pyrexia) as a major disease that is contrary to biomedicine in which fever is only a symptom. Currently, COVID-19 is a rapidly changing and evolving situation. World Health Organisation (WHO) is constantly monitoring it and updating the information available regarding its spread, mortality, and morbidity. So far in Modern Western Medicine (MWM), no exact cure has been found which is specific to COVID-19. A retrospective literature review with Jwara based on Samhithas can enhance the approach and treatment strategies, which can repurpose with any emerging diseases. It is important to evaluate the benefits of Jwara centric approach in the understanding and treatment of COVID-19. So, the textual reference and description of the fundamental treatment approach on Jwara were taken and analysed from Ayurveda Brihathrayee Samhithas and relevant scientific publications.

\section{Literature review on Jwara with Brihathrayee Importance of Jwara. ${ }^{3}$}

Jwara (fever) is the lord of the diseases, born from sin, causing death, feeds on Ojas (the essence of the tissue), leads to the end (death), originated from the upper eyes of Rudra (Lord Siva) who destroyed the sacrifice of Daksa, by wrath (of being insulted); it is a producer of delusion at the time of birth and death (of living beings) characterised by (producing) Santapa (discomfort by heat), arising from improper conduct (regarding food, activities etc.), a cruel one, affecting all the species of living beings and called by different names. Acharya Charaka explains it is the first to be manifested among all the diseases. It is exceedingly powerful. This enemy of a human being is invariably associated with dissolutions and creations.

\section{Jwara Nidana ${ }^{4}$}

Generally, Nidana for Jwara can be explained as due to Mithyahara Vihara or it can be the caused due to Nidana causing the Dushti of concerned Dosha.

\section{Types of $\boldsymbol{J w a r a}^{5}$}

Jwara occurs in humans due to eight causative factors, - Vata, Pitta, Kapha, Vata-Pitta, Vata-Kapha, PittaKapha, Vata-Pitta-Kapha, and Agantu (exogenous causes).

\section{Samprapti $^{6}$}

Malas (Doşhas) getting increased by their respective causes, enter the Amasaya (stomach), combine with Ama (undigested or improperly processed metabolites present in the alimentary tract), obstruct the channels (of Rasa Dhatu present in the digestive tract), drive the fire (digestive agency) to the exterior (skin and other tissues) and moving along with it (fire, heat) make for the great increase of the heat of the body-thus generate Jwara (fever), Because of the obstruction of the channels of sweat by the Doshas mixed with Amat sweating does not occur generally (despite an increase of temperature).

\section{Poorva roopa $^{7}$}

Its premonitory symptoms are lassitude, lack of interest in anything, lachrymation, feeling of heaviness of the body, bad taste in the mouth, loss of appetite, (too much of) yawning, eyes full of tears, body ache, indigestion, poor strength, excess sleep, horripilation's, bending and drooping of the body parts, depletion in strength and complexion, cutting pain in the calves, exhaustion (even without any strain), impatience towards good advice, desire for things of sour, pungent and salt tastes, heartedness towards sweet eatables and children; severe thirst, like or dislike for sound (pleasant sound of music etc.), fire (sitting near the fire), cold breeze, cold water, shade and sunlight without any apparent reason. Following these, the manifestation of fever takes place. 


\section{Roopa $^{8}$}

Obstruction (absence) of sweating, Santapa (temperature), Aruci (anorexia), Trsna (morbid thirst), Angamarda (malaise), Hrid-Vyatha (pain in the cardiac region)-these are the invariable manifestations of Jwara. At the beginning of the birth and during death, it is manifested in the form of Tamas (entering darkness). Apart from this Jwara symptoms will be changed based on the Dosha Beda.

\section{Prognosis ${ }^{9}$}

Charaka explains Sadhya (curable) Jwara as Jwara is easily curable if it occurs in a person with a strong physique, or if it is caused by the vitiation of a lesser amount of Dosha and if there are no complications. Asadhya (incurable) Jwara as Jwara having the following characteristics are incurable and lead to death. Tikshna Jwara (severe, associated with delirium, giddiness and breathlessness) causes the death of the patient either on the seventh, tenth or twelfth day. Jwara occurring in a week and emaciated person, associated with oedema, seated in deeper body tissues, severe and that occurring for very long durations are incurable ones. The Jwara in which, the mid hair part of the scalp becomes visible, is also considered incurable.

Acharya Sushruta adds up, the severity of fever depends on the mild, moderate and profound aggravation of the Doşhas, remaining for three, seven and twelve days respectively; they are easy to treat in their preceding order. These are the days of yama (death), and death is certain in these days; after they (fevers) quit the body further life is called as "rebirth" itself.

\section{Chikitsa krama of Jwara ${ }^{10}$}

Langhana (fasting), Svedana (sudation, diaphoresis), Kala (awaiting time), Yavagu (drinking of thin gruel), use of (drugs) of bitter taste and Pachana (drugs) which cook (transform by heat) the Doshas-these should be administered either as suitable to the stages (of fever) or in successive order.

\section{Langana ${ }^{11}$}

The Doşhas residing in (got localised in) the Amasaya (stomach) destroy the fire (digestive activity), become Sama (mixed with undigested materials) obstruct the passages (of Rasa Dhatu) and produce fevers; therefore, Langhana (fasting) should be done either during the premonitory stage or at the commencement of fevers, safeguarding the strength (of the body) with all efforts; health depends on the strength and the purpose of treatment is the maintenance of health.

When the Doșhas become reduced by fasting, the digestive power becomes increased and feeling of lightness of the body appears, health, (comfort), hunger, thirst, desire for food, good digestion, strength and vitality (enthusiasm) also manifest. Fasting should not be advised in fever produced by Vata, Kșaya (decrease of tissues) and Manasa (mental disorders). When the Doshas and Agni (digestive fire) have moved out of their usual seats, then fasting ripens the Doshas, relieves fever, increases hunger, desire for food, taste and bestow a feeling of lightness to the body

Peyadi krama ${ }^{12}$

When the patient is found to have developed the symptoms of proper Langhana therapy, he should be treated next, with the administration of Peya etc. (drinking of gruel), prepared with drugs appropriate to each Dosha commencing first with Manda, either for six days or till the fever become soft (mild). By these (different kinds of gruel) his digestive fire gets increased just as the (external) fire, by the faggots (small pieces of wood).

\section{Aushada Krama ${ }^{13}$}

After the sixth day, from the beginning of the onset of Jwara, i.e., on the seventh day, the patient should be given a light diet in appropriate quantity. Thereafter, on the eighth day of the fever, decoction should be given to the patient. Acharya Susrutha add up, Scholars opine those medicines should be given to the patient of fever after seven days; some others say decidedly that it should be given after ten days. In case of fevers of pitta origin, though of recent origin medicine may be administered, because of the quick ripening of the Doshas in them. Administering medicines when the Doshas are in an unripe state increases the fever; medicines that are purificatory and palliative (if administered in the unripe stage) give rise to Visama Jwara (intermittent fevers). 


\section{DISCUSSION}

Pyrexia (fever) is one of the prevalent symptoms manifested with COVID-19. Many studies have observed that more than half of infected patients are suffering from fever ${ }^{14}$. The COVID-19 disease pathology, manifestation as per the Ayurveda approach provides an insight that it is more a Vata-Kapha ${ }^{15}$ Dosha Pradhana with Aupasarkiga in nature. The clinical profile study also establishes the approach of considering COVID19 as a Vata-Kapha dominant disease. A comprehensive approach to manage the fever is important in COVID-19 since it is one of the most prevalent symptoms and more than a symptom it also becomes a tool to evaluate prognosis. The inflammatory response associated with fever is vital as the level of inflammatory-immune response becomes vital in the systemic involvement of COVID-19. The Ayurveda approach towards Jwara (fever) becomes more relevant as it is having a more solid and comprehensive understanding. The Ayurveda consider the initial 6 days of Jwara treatment as Shadaha Chikitsa as in the period where no extensive treatment will be done. The concept of Shadaha Chikitsa relies upon the fact that the body's inherent metabolic fire (Agni) needed to stabilise on its own to heal the Jwara comprehensively. In that period the medicine used is less potent like Thoya, Paneeya (herbal drink form) which will only facilitate the healing process. The diet and lifestyle guidelines have utmost importance in this period. Initially, fasting is suggested to reduce the burden of the metabolic system which is already hampered by Jwara and to facilitate better healing. Through ignition of Agni (metabolic fire), the patient can be allowed to consume little light and warm food. Excess cooked rice/gruel proceeded with herbs are also suggested after once Agni is being ignited. Unless there is any worsening of symptoms during Shadaha period there is no need for any potential medicinal formulations. The emerging observations also suggest the fever to be handled naturally and not to suppress with any Antipyretic medicines as considering fever to be vital immune feedback.

The availability of some of the biomedical evidence is also backing up the Ayurveda approach to manage Jwara. The utility of fasting ${ }^{16}$ is observed to be Anti- inflammatory, immune-modulatory and Antioxidant. Thus, proper Application of fasting based on Ayurveda rationality can contribute to better healing, better prognosis in COVID-19 also. One of the article ${ }^{17}$ published in the public health journal emphasises the importance of manifestation fever in terms of regulating immune mechanisms and clearing the underlying infection. The Ayurveda herbs and polyherbal combinations which have the potential of Jwaragna (Antipyretic) are being evaluated for their therapeutic effectiveness in managing COVID-19 in Phytochemical profiling, in vivo-in vitro and clinical trials. Thus, it outlines that the Ayurveda approach of Jwara management is highly beneficial not only in symptomatic improvement but also with the COVID-19 disease recovery. Ayurveda Jwara approach can be considered as a major strategy that can be Adapted for the safe and effective management of COVID-19.

\section{CONCLUSION}

The extensive literature review on Jwara with Samhithas makes the understanding and treatment approach towards the Jwara to be more clear and solid. the depth Samhithas based retrospective review of Jwara will enable the repurposing of its theory and management towards similar manifested conditions. The Jwara centred approach towards COVID-19 may also contribute towards better management of the disease.

\section{REFERENCES}

1. Vagbata, Ashtanga hridayam, sarvangasundara commentary by Arunadatta Reprinted ed., nidana sthana (2:1), pg. 447 Chaukhamba krishnadas academy Varanasi, (2018)

2. Vagbata, Ashtanga hridayam, sarvangasundara commentary by Arunadatta Reprinted ed., nidana sthana (2:2), pg. 447 Chaukhamba krishnadas academy Varanasi, (2018)

3. Vagbata, Ashtanga hridayam, sarvangasundara commentary by Arunadatta Reprinted ed., nidana sthana (2:1 - 2), pg. 447 Chaukhamba krishnadas academy Varanasi, (2018)

4. Vagbata, Ashtanga hridayam, sarvangasundara commentary by Arunadatta Reprinted ed., nidana sthana 
(2:3), pg. 448 Chaukhamba krishnadas academy Varanasi, (2018)

5. Vagbata, Ashtanga hridayam, sarvangasundara commentary by Arunadatta Reprinted ed., nidana sthana (2:3), pg. 447 Chaukhamba krishnadas academy Varanasi, (2018)

6. Vagbata, Ashtanga hridayam, sarvangasundara commentary by Arunadatta Reprinted ed., nidana sthana (2:4 - 5), pg. 448 Chaukhamba krishnadas academy Varanasi, (2018)

7. Vagbata, Ashtanga hridayam, sarvangasundara commentary by Arunadatta Reprinted ed., nidana sthana (2:6 - 9), pg. 448 Chaukhamba krishnadas academy Varanasi, (2018)

8. Susruta, Susrutha Samhita, Nibandhasangraha commentary by Dalbana acharya, revised ed., uttara tantra (39:25 - 28), pg. 672, Chaukhamba krishnadas academy Varanasi, (2014)

9. Agnivesha, Charaka Samhita, Ayurveda- Dipika commentary by Chakrapanidutta, revised ed., Chikitsa Sthana (3:50 - 52), pg. 403, Chaukhambha Surbharati Prakashan, Varanasi, (2005)

10. Agnivesha, Charaka Samhita, Ayurveda- Dipika commentary by Chakrapanidutta, revised ed., Chikitsa Sthana (3:142), pg. 409, Chaukhambha Surbharati Prakashan, Varanasi, (2011)

11. Vagbata, Ashtanga hridayam, sarvangasundara commentary by Arunadatta Reprinted ed., chikitsa sthana (1:1 - 4), pg. 448 Chaukhamba krishnadas academy Varanasi, (2018)

12. Agnivesha, Charaka Samhita, Ayurveda- Dipika commentary by Chakrapanidutta, revised ed., Chikitsa Sthana (3:150 - 151), pg. 409, Chaukhambha Surbharati Prakashan, Varanasi, (2011)

13. Susruta, Susrutha Samhita, Nibandhasangraha commentary by Dalbana acharya, revised ed., uttara tantra (39:119 - 122), pg. 681, Chaukhamba krishnadas academy Varanasi, (2014)

14. Puthiyedath R, Kataria S, Payyappallimana U, Mangalath P, Nampoothiri V, Sharma P, Singh MK, Kumar K, Trehan N. Ayurvedic clinical profile of COVID-19 - A preliminary report. J Ayurveda Integr Med. 2020 Jun 12: S0975-9476(20)30039-5. doi: 10.1016/j.jaim.2020.05.011. Epub ahead of print. PMID: 32624376; PMCID: PMC7290222.

15. Puthiyedath R, Kataria S, Payyappallimana U, Mangalath P, Nampoothiri V, Sharma P, Singh MK, Kumar K, Trehan N. Ayurvedic clinical profile of COVID-19 - A preliminary report. J Ayurveda Integr Med. 2020
Jun 12: S0975-9476(20)30039-5. doi: 10.1016/j.jaim.2020.05.011. Epub ahead of print. PMID: 32624376; PMCID: PMC7290222.

16. Wrotek S, LeGrand EK, Dzialuk A, Alcock J. Let fever do its job: The meaning of fever in the pandemic era. Evol Med Public Health. 2020 Nov 23;9(1):26-35. doi: 10.1093/emph/eoaa044. PMID: 33738101; PMCID: PMC7717216.

17. Wrotek S, LeGrand EK, Dzialuk A, Alcock J. Let fever do its job: The meaning of fever in the pandemic era. Evol Med Public Health. 2020 Nov 23;9(1):26-35. doi: 10.1093/emph/eoaa044. PMID: 33738101; PMCID: PMC7717216.

\section{Source of Support: Nil Conflict of Interest: None Declared}

How to cite this URL: Visakh V \& Soumya Saraswathi M: Ayurveda Samhitha Based Literature Review On Jwara And Relevance Of Jwara Centered Approach In Management Of Covid-19. International Ayurvedic Medical Journal \{online\} 2021 \{cited October 2021\} Available from: http://www.iamj.in/posts/images/upload/2522_2526.pdf 